\title{
Erratum to: Predictors of psychological well-being and stress among Jordanian menopausal women
}

Rania Y. Abdelrahman • Lubna A. Abushaikha •

Mohammad A. al-Motlaq

Published online: 19 October 2013

(C) Springer Science+Business Media Dordrecht 2013

Erratum to: Qual Life Res

DOI 10.1007/s11136-013-0464-z

The original publication of the article includes an error in the affiliation of the co-author L. A. Abushaikha.

The correct affiliation is given below.

The online version of the original article can be found under doi:10.1007/s11136-013-0464-z.

R. Y. Abdelrahman · M. A. al-Motlaq ( $₫)$

Hashemite University, Zarqa, Jordan

e-mail: mohammada_m@hu.edu.jo

L. A. Abushaikha

The University of Jordan, PO Box 11942, Amman, Jordan 